\title{
NEW SPECIES, VARIETIES AND COMBINATIONS FROM THE COLLECTIONS OF THE ARNOLD ARBORETUM
}

\author{
Alfred Rehder
}

\section{Abies Ermesti, nom. nov.}

Abies firma Masters in Jour. Linn. Soc. Bot. 37: 422 (1906), non Sieb. \& Zucc.

Abies Beissneriana Rehder \& Wilson in Sargent, P1. Wilson. 2: 46 (1914). - Chun, Chin. Econ. Trees, 30 (1922). - Dallimore \& Jackson, Handb. Conif. 87 (1923) ; ed. 2, 87 (1931). - Rehder in Bailey, Cult. Evergr. 254 (1923); Man. Cult. Trees Shrubs, 32 (1927). Fitzpatrick in Sci. Proc. Roy. Dublin Soc. 19: 207 (1929). - Viguié \& Gaussen in Bull. Soc. Hist. Nat. Toulouse, 58: 272 (Rev. Gen. Abies 94) (1929). — Fitschen in Beissner, Nadelholzk. ed. 3, 133 (1930). Bailey, Cult. Conif. 85 (1933). - Li, For. Bot. China, 30 (1935). Non Mottet (1902).

Since the name Abies Beissneriana Rehd. \& Wils. is a later homonym of $\times$ A. Beissneriana Mottet in Rev. Hort. 1902: 163, a hybrid of $A$. Nordmanniana and Pinsapo, ${ }^{1}$ and therefore not valid, this species may bear the name of its discoverer, Ernest $\mathrm{H}$. Wilson, who introduced it into cultivation in 1904 and again in 1908, but at present it is rare and only a few trees are known to exist in England (cf. Rep. Conif. Confer. Roy. Hort. Soc. pp. 225, 353. 1931), and in France probably raised from seed from "Tnong-Kong," sent in 1924 by the French consul at Chengu-tu (cf. Viguié \& Gaussen, l.c.).

Picea notha (P. Glehnii [Fr. Schmidt] Mast. $\& \times$ jezoensis var. hondoensis [Mayr] Rehd.), hybr. nov.

Arbor habitu Piceae Glehnii; ramuli brunnei sparse pilosi, sterigmatibus angulo recto divergentibus $0.75 \mathrm{~mm}$. longis basi tumidis: gemmae conico-ovoideae obtusiusculae, fusco-brunneae, valde resinosae, squamis paucis acuminatis dimidiam gemmam non excedentes, folia ramulorum robustiorum circiter $1.5 \mathrm{~cm}$. longis et circiter $1.25 \mathrm{~mm}$. latis, ramulorum tenuiorum minora, apice abrupte in mucronem obtusiusculum contracta, falcata, ramum supra dense et subadpresse tegentia, subtus fere pectinatim patentia, ventre carinata fasciebus duobus albis e seriebus stomatum 5-7 compositis, dorso lucida laete viridia, leviter ob${ }^{+}$useque carinata utrinsecus stomatum seriebus $1-2$, rarius 3, partim incompletis notata. Strobili cylindrico-oblongi, 4.5-5.5 cm. longi, im$1=$ Abies insignis Carr. var. Beissneriana (Mottet) Rehder in Jour. Arnold Arb. 1: 54 (1919). 
maturi virides, squamis laxe adpressis flexibilibus rhombico-ovatis $1 \mathrm{~cm}$. longis et 7-8 mm. latis leviter striatis et undulatis, apice rotundatis vel supra medium angustatis et truncatis eroso-denticulatis, bracteis triangulari-ovatis circiter $3 \mathrm{~mm}$. longis; semina ala inclusa quam squama triente breviora. Proxima Piceae jezoensi var. hondoensi, quae facile distinguitur ramulis ochraceis glabris, gemmis bracteis subulatis carentibus, foliis non falcatis, dorso stomatibus destitutis atroviridibus, ventre fasciebus stomatum latioribus magis candidis, strobili squamis angustioribus magis undulatis et erosis apice saepius emarginatis. Picea Glehnii, parens feminea, differt ramulis densius pilosis, gemmis basi squamis subulatis gemmae subaequilongis, sterigmatibus brevioribus non tumidis, foliis minoribus 6-12 mm. longis leviter compressis, fasciebus stomatiferis ventre e seriebus stomatum 4-5, dorso 1-3 compositis, strobilis squamis firmis rotundatis, $1-1.4 \mathrm{~mm}$. latis nitidulis margine integro vel vix denticulatis.

Cult. Arnold Arboretum under no. 13406, raised from seed received in 1894 from the Government Forestry School, Tokyo. Specimens in herb.: Coll. A. Rehder, April 5, 1917 (sterile); coll. A. Rehder E E. J. Palmer, Sept. 28, 1936 (fruiting; type).

From the seed received in 1894 as Picea Glehnii about 15 plants were planted, one of which turned out to be the hybrid described above, all the others were true $P$. Glehnii. The seeds must have been collected from a tree or trees growing in the vicinity of trees of $P$. jezoenis var. hondoensis, and the flowers partly pollinated by the latter. The tree growing here is about $8 \mathrm{~m}$. tall and is clearly intermediate between $P$. Glehnii and $P$. jezoensis var. hondoensis, though in general appearance resembling the latter; from $P$. Glehnii it is easily distinguished by the less pilose branchlets, by the longer sterigmata much thickened at base, the larger compressed leaves with fewer stomatic lines on the dorsal and more numerous lines on the ventral side, and by the cones with flexible, narrower and distinctly erose-denticulate scales; from the latter it differs in the pilose brown branchlets, in the presence of a few stomatic lines on the dorsal side of the leaves and in the broader less undulate cone-scales.

Taxodium distichum (L.) Rich. f. pendens, nom. nov.

Taxodium distichum nutans Carrière, Traité Conif. ed. 2, 183 (1867). Beissner, Handb. Nadelholzk. 152 (1891). - Non T. d. var. nutans (Ait.) Sweet.

Taxodium distichum pendulum Horsey in Horticulture, Boston, ser. 2, 3: 446, fig. (1925). - Slavin ex Bailey, Cult. Conif. 138 (1933), pro var. - Non T. d. pendulum (Endl.) Carr. 
A form of typical $T$. distichum with slender pendulous branchlets with the leaves usually somewhat more distant than in the type. This is the form referred to in the remarks under $T$. ascendens f. nutans in Jour. Arnold Arb. 7:22 (1926), where in the citations of synonyms under $T$. distichum pendulum, the reference to Horsey should be eliminated.

Thuja occidentalis f. Mastersii, nom. nov.

Thuia plicata Endlicher, Syn. Conif. 51 (1847), pro parte. - Carrière, Traité Conif. 102 (1855), pro parte. - Gordon, Pinet. 325 (1858) “Thuja," ex parte. - Henkel \& Hochstetter, Syn. Nadelhölz. 277 (1865), pro parte. - Parlatore in D.C., Prodr. 457 (1868), “Thuja.”Beissner, Handb. Nadelholzk. 44 (1891). - Non Lambert (1824).

Thuja occidentalis plicata Wells in Proc. Roy. Hort. Soc. 3: 303 (1863), nom. nud.

Thuya occidentalis var. plicata Masters in Gard. Chron. ser. 3, 21:258 fig. 86 (1897). - Kent in Veitch, Man. Conif. ed. 2, 247 (1900). Beissner, Handb. Nadelholzk. ed. 2, 504 (1909). - Rehder in Bailey, Cult. Evergr. 223 (1923) "Thuja"; Man. Cult. Trees Shrubs (1927). - Dallimore \& Jackson, Handb. Conif. 511 (1923) “Thuja." - Non Hoopes (1868).

Since Thuja occidentalis var. plicata Mast. is a later homonym of Th. occidentalis var. plicata Hoopes, Book Evergr. 321 (1868) a new name is needed for this garden form and it may well bear the name of Masters who first cleared up the existing confusion between this form and the western species. Hoopes' name is based, at least as to the name bringing synonym and the habitat, on Th. plicata Lamb., and must stand as the correct name for this tree, if transferred to Th. occidentalis as a variety.

Ulmus procera f. myrtifolia, f. nov.

Ulmus campestris var. myrtifolia Hort. ex Nicholson in Kew Hand-list Trees Shrubs, 2: 135 (1896), nom. nud.; op. cit. ed. 2, 615 (1902); op. cit. ed. 3, 271 (1925), nom. nud.

Ulmus buxifolia Hort. ex Nicholson, 1. c., pro synon. praeced.

Ulmus procera var. myrtifolia Bean in Kew Hand-list Trees Shrubs, ed. 4, 341 (1934), nom. nud.

Arbor ramis gracilibus. Folia ovata vel rhombico-ovata rarius oblongo-ovata, $2-5 \mathrm{~cm}$. longa, basi obliqua, serrata dentibus simplicibus vel infra denticulo parvo instructa, utrinque laxe pilosis, subtus praecipue ad venas; petiolus 2-4 mm. longus. Fructus obovatus, 12-15 mm. longus; semen apicem clausum attingens.

Kew Arboretum, Geo. Nicholson, July 22, 1880 (as U. myrtifolia Volxem), type. Hort. Mrs. R. H. Bole, Cleveland, Ohio, June 15, 1927. 
This form of $U$. porcera differs chiefly in its small leaves from typical $U$. procera, and in this respect is similar to $U$. procera var. viminalis (Loud.) Rehd., but this has longer and narrower, incisely serrate leaves. The second specimen agrees well with the first, but on the more vigorous shoots, the leaves are narrower and longer, up to $5 \mathrm{~cm}$. long, resembling somewhat those of var. viminalis, while in the type specimen they are only $2-3 \mathrm{~cm}$. long and always rhombic or rhombic-ovate; the description of the fruit is based on this specimen, the type specimen being sterile. Plants from the tree in Cleveland are growing in this Arboretum.

The plant known as $U$. campestris myrtifolia purpurea DeSmet $=U$. procera f. purpurascens (Schneid.) Rehd. has generally larger leaves and is not a purple-leaved variation of the form described above.

Ulmus pumila L. f. Androssowi (Litvin.), comb. nov.

Ulmus Androssowi Litvinov in Sched. Herb. Fl. Ross. 8: 23, 202, t. 2 (1922).

Turkestan: city of Samarkand, cult., Bubyr \& Androssov, March 5, April 18 and July 29, 1913 (Herb. Fl. Ross. no. 2445, isotype, 3 sheets; 3 photos. of type). Taschkent, cult., Bubyr \& Androssov Feb. 14, March 29, Sept. 11, 1914 (Herb. Fl. Ross. no. 2788).

This form differs from typical $U$. pumila in its very dense spherical crown and also in the pubescent leaves which are usually glabrous in $U$. pumila. It is known only as a cultivated tree and has been much confused with $U$. carpinifolia Gled. var. umbraculifera (Trautv.) Rehd. (U. campestris var. umbraculifera Trautv., U. turkestanica Reg., p. p.) which Litvinov cites as pro parte synonyms of his $U$. Androssowi. Both are planted in Turkestan as street trees, sometimes together on the same street, as shown by a photograph taken by Androssov in Samarkand (in Sched. Herb. Fl. Ross. 8: t.2). Though similar in habit, $U$. pumila f. Androssowi may be easily distinguished from $U$. carpinifolia var. umbraculifera by the grayish or grayish brown bark of the branchlets with conspicuous corky wings on older branches, by the pubescent winter-buds, by the leaves being shallowly and mostly simply serrate, loosely villous beneath and by the suborbicular fruit 10-13 mm. in diam., with the seed slightly above the middle; in $U$. carpinifolia var. umbraculifera the branchlets are conspicuously red-brown and do not become corky, the leaves are more sharply and more distinctly doubly serrate, only slightly puberulous beneath when young, soon glabrous, and the obovate fruit is cuneate at base and about $1.5 \mathrm{~cm}$. long, with the seed close to the notch and well above the middle. Sterile specimens of the two elms may not 
always be easy to distinguish, but the characters of the fruit are constant and reliable.

Ulmus pumila is very variable in habit and leaf characters. It was originally based by Linnaeus (Sp. Pl. 226) on the shrubby form from Siberia, but Pallas (Fl. Ross. 1: 76, t.48. 1788) included an arboreous form (fig. D) from southern Russia with it. This plant, however, does not belong to $U$. pumila, but represents $U$. carpinifolia whose range extends from Europe to Transcaucasia and reaches its eastern limit in Turkestan, where $U$. pumila reaches its furthest western extension. One of the first authors to include in $U$. pumila the tree form from $\mathrm{N}$. China was Planchon (in D.C., Prodr. 17:159. 1873) and all later authors followed him until Nakai in 1932 (Fl. Sylv. Kor. 19: 22) separated the tree of Korea, Manchuria and northern China as $U$. manshurica; he also considers the arboreous form of Turkestan, U. pumila var. arborea Litv., a distinct species for which he adopted the name $U$. pinnato-ramosa Dieck. I cannot see any specific difference between the tree-like and shrubby form; both forms occur in Manchuria and northern China and are probably only ecological variations caused by soil and climatic conditions. Skvortzov in Lingnan Sci. Jour. 6: 208 (1928) describes a var. genuina as a round-topped tree with erect branches and distinguishes three forms based on size and shape of the fruit; in Bull. Jard. Bot. U.R.S.S. 28: 544 a year later, he describes two more varieties, but rather briefly and as in the preceding publication, without citation of locality or specimens; he does not mention a shrubby form. The form in general cultivation is the tree-like form.

Clematis Armandi Franchet in Nouv. Arch. Mus. Paris, ser. 2, 8: 184, t.2 (Pl. David. 2: 2, t.2) (1885). - Finet \& Gagnepain in Bull. Soc. Bot. France, 50:526 (1903); Contrib. Fl. As. Or. 1: 11 (1905); in Lecomte, Fl. Gén. Indochine, 1: 3 (1907). - Rehder \& Wilson in Sargent, Pl. Wilson. 1:326 (1913), pro parte. - P'ei in Sinensia, 6:388 (1935).

Clematis hedysarifolia $\gamma$ Armandi Franch. pr. sp. in msc. ex Kuntze in Verh. Bot. Ver. Brandenb. 26: 152 (1885, May 28).

Clematis ornithopus Ulbrich in Rep. Spec. Nov. Beih. 12: 375 (1922).

The type of $C$. Armandi is characterized by a solitary peduncled and leafy inflorescence, and by rather small flowers $2.5-3.5 \mathrm{~cm}$., across with 4 or 5 petals. This form is rather rare and represented in this herbarium by only six specimens from Hupeh, Szechuan, Hunan and Yunnan; also $C$. ornithopus Ulbrich belongs here. Much more com- 
mon are the forms with 4 or 5 sepals and leafless panicles. Of this, two forms may be distinguished: one with a solitary peduncled inflorescence represented in this herbarium by three specimens from Szechuan, three from Yunnan, two from Hunan and one from Annam; and one with mostly sessile or subsessile inflorescences represented by three specimens from Hupeh, two specimens from Szechuan and three from Yunnan. The last named form represents a transition to the following variety which has the inflorescence also branching from the base, but has larger flowers about 4-6 cm. across with 5-7, usually 6, broader petals.

Clematis Armandi var. Biondiana (Pavol.), comb. nov.

Clematis Armandi Finet \& Gagnepain in Bull. Soc. Bot. France, 50: 526 (1903) ; Contrib. Fl. As. Or. 1: 11 (1905), pro parte. - Pampanini in Nuov. Giorn. Bot. Ital. n. ser. 17, 2: 269 (1910). - Rehder \& Wilson in Sargent, Pl. Wilson. 1: 326 (1913), pro parte. - Sprague in Bot. Mag. 140: t. 8587 (1914).

Clematis Biondiana Pavolini in Bull. Soc. Tosc. Ort. 32: 285 (1907); in Nuov. Giorn. Bot. Ital. n. ser. 15: 401 (1908). - P'ei in Sinensia, 6: 389 (1935).

This variety differs chiefly in its larger flowers $3.5-6.5 \mathrm{~cm}$. across with 5-6, sometimes 7 sepals; its inflorescence is leafless and sessile, branching from the very base which gives the inflorescence the appearance of several axillary panicles. It is represented in this herbarium by a photograph of the syntype from Sian Men K'vn (Silvestri no. 627), by Silvestri no. 629 and five other specimens from Hupeh; of these Wilson's specimen no. 95 from Chanyang Hsien and an unnumbered Henry specimen differ in the panicles being partly leafy and leafless on the same specimen. This variety is the commonly cultivated form; among the illustrations in horticultural publications which I compared, I found 15 illustrations representing var. Biondiana and only two, one by Mottet in Rev. Hort. n. ser. 13: 65, fig. 18 (1913), and one by Lemperg in Gartenschönh. 9:284, fig. (1928) which clearly represent the typical form of $C$. Armandi.

Clematis Armandi f. Farquhariana Rehder \& Wilson in Sargent, Pl. Wilson. 1:327 (1913).

Clematis Armandi var. Farquhariana Rehder, Man. Cult. Trees Shrubs, 225 (1927) pro parte, excl. syn. \& fig. cit.

This form differs from the preceding variety only in the pale pink color of its flowers. It is represented in this herbarium only by the type specimen and is apparently not in cultivation.

Clematis Armandi grandiflora Mottet in Rev. Hort. n. ser. 17: 276, 
fig. 68 (1921); Arb. Arbust. Orn. 20, fig. 3 (1925), pro var., is probably a hybrid according to Mottet; it has sometimes 5 or 7 leaflets, more coriaceous than in $C$. Armandi and purple when unfolding, while $C$. Armandi has constantly 3 -foliolate leaves. Mottet states that the plant was received from La Mortola. There is a specimen under this name received from Hort. Vilmorin in this herbarium with 3 -foliolate leaves differing from $C$. Armandi only in the narrowly elliptic sepals overlapping at the base and only $18 \mathrm{~mm}$. long.

Clematis koreana Komar. f. lutea, f. nov.

Clematis koreana var. lutea [Bean in] Kew Hand-list Trees Shrubs, 68 (1934), nom. nud.

Forma floribus luteis.

Clematis koreana was originally described by Komarov (in Act. Hort. Petrop. 18:438. 1904) as varying with yellow flowers in open situations, or with violet flowers in moist and shady situations. There is no indication which he considers typical. In a flowering specimen from Korea (Wilson 8616) the flowers are described as reddish, while in a specimen from Manchuria (Komarov 703) the flowers seems to be yellow. A variety described and figured by Nakai as C. koreana var. umbrosa (in Matsamura, Icon. Pl. Koishik. 4: 107, t.266. 1921) is stated to have purple-red flowers. In a cultivated specimen from the Dendrological Garden at Pruhonice, Czechoslovakia, collected 1923, the flower is unmistakably violet, while a cultivated plant figured by $\mathrm{F}$. Lemperg (in Gartenschönh. 9:286) is stated to have yellow flowers. Since the yellow-flowered has been separated, at least in gardens, as a distinct form, it seems best to consider the plant with violet or reddish flowers as typical.

Magnolia Wilsonii (Fin. \& Gagnep.) Rehd. f. Nicholsoniana (Rehd. \& Wils.), comb. nov.

Magnolia Nicholsoniana Rehder \& Wilson in Sargent, P1. Wilson. 1: 394 (1913). - Wilson in Jour. Arnold Arb. 7: 235 (1926). - Millais, Magnolias, 178 (1927).- - Rehder, Man. Cult. Trees Shrubs, 255 (1927).

Magnolia taliensis W. W. Smith in Notes Bot. Gard. Edinb. 8: 341 (1915).

Magnolia liliifera var. taliensis Pampanini in Bull. Soc. Tosc. Ort. ser. 4, 1: 137 (1916).

Magnolia Wilsonii (Fin. \& Gagnep.) Dandy in Notes Bot. Gard. Edinb. 16: 126 (1928), pro parte, quoad synon. M. Nicholsoniana et M. taliensis.

Specimens examined: S z e chua n, E. H. Wilson 838 (type of 
M. Nicholsoniana); $\mathrm{Y}$ u n n a n, G. Forrest 15476, J. F. Rock 8620, 8639, S. Ten 302, 564.

This form differs from $M$. Wilsonii in its leaves being glaucescent and glabrescent beneath except the rufous-pilose midrib, while $M$. Wilsonii has the underside of the leaves densely covered with long subappressed white silky hairs. The latter is represented in this herbarium by the following specimens: $\mathrm{S} z$ e c h u a n : Wilson 1374 and Veitch Exp. 3137, Harry Smith 1953; Y un n a n: S. Ten 500, 593; also by several cultivated specimens. According to Dandy the material from Yunnan displays all intermediate degrees of hairiness; one of these intermediate forms is represented by Ten 593 which has the mature leaves only slightly and thinly pubescent. Intermediate forms, however, seem to be rare, and as the dense silky pubescence of the underside of the leaves gives the foliage quite a distinct aspect from that of the glabrescent form, it seems desirable, particularly from a horticultural point of view, to keep the glabrescent plant distinct, at least as a form.

Lindera aestivalis (L.) Bl. f. xanthocarpa (G. S. Torr.), comb. nov.

Benzoin aestivale f. xanthocarpum G. S. Torrey in Rhodora, 16:91 (1914).

Since the proposition to conserve Lindera Thunb. against Benzoin Fabric. had the majority of votes of the Special Nomenclature Committee for Phanerogamae and Pteridophyta appointed in 1935 by the International Botanical Congress, a new combination is necessary for the yellow-fruited form published under Benzoin aestivale.

Hydrangea serrata f. prolifera (Reg.), comb. nov.

Viburnum cuspidatum Thunberg, F1. Jap. 125 (1785).

Hydrangea stellata Siebold \& Zuccarini, F1. Jap. 1: 112, t. 59 (1840).

Hydrangea stellata $\beta$ prolifera Regel in Gartenfl. 25: 291, t. 521 (1866).

Hydrangea cuspidata Miquel in Ann. Mus. Bot. Lugd.-Bat. 3:98

(1867). - Koidzumi in Bot. Mag. Tokyo, 39: 311 (1925).

Hydrangea opuloides var. prolifera Rehder in Bailey, Stand. Cycl. Hort. 3: 1622 (1915).

Hydrangea serrata var. stellata Wilson in Jour. Arnold Arb. 4:245 (1923), which see for further citations of synonyms and literature.

Hydrangea cuspidata (Thbg.) Miq. var. japonica (Sieb.) Koidzumi in Bot. Mag. Tokyo, 39:311 (1925), pro parte.

Wilson when making the combination $H$. serrata var. stellata overlooked the fact that the oldest varietal epithet of this plan is "prolifera."

Viburnum cuspidatum Thunb. of which I examined the type and photographed it when in Uppsala in 1928, is referable to this form, 
since it has all the flowers sterile, though the leaves are somewhat different being more sharply and closely serrate with a somewhat slenderer acumen than those of Viburnum stellatum $\alpha$ of Thunberg's herbarium which also represents this form and agrees more closely with the plant cultivated as typical "stellata" and with Regel's plate of $H$. stellata var. prolifera.

Koidzumi in 1912 (in Bot. Mag. Tokyo, 26:388) had identified Hydrangea cuspidata (Thunb.) Miq. with $H$. involucrata Sieb. and quoted the latter as a synonym of the former, but changed his opinion in 1925 after he had seen Thunberg's type; however, he did not pay any attention to the fact that Viburnum serratum and V. cuspidatum represent garden forms with all the flowers sterile.

Liquidambar Styraciflua L. f. pendula, f. nov.

A typo recedit ramis pendulis; arbor trunco excurrente ramis deflexis longis pendulis comam angustam formantibus.

This interesting new form was discovered near Hatton, Arkansas, about 1935 by Miss Sara W. Crawford. Only a single tree was found, of which Miss Crawford kindly sent us a leafy branch and photographs of the whole tree in summer and winter condition, (specimen coll. Sara W. Crawford, Oct. 9, 1938, and three photographs in herb. Arnold Arb.). We are also obliged to her for pieces of living root, from which we hope to propagate this tree. The tree observed is about $18 \mathrm{~m}$. tall with a slender trunk about $23 \mathrm{~cm}$. in diameter breast high; the straight upright trunk bends over at the top for about $3 \mathrm{~m}$. and is clothed to the ground with deflexed pendulous branches of nearly equal length forming a slender narrow crown.

Of another interesting form of the sweet-gum, L. Styraciflua f. rotundiloba Rehd. (in Jour. Arnold Arb. 12: 70, 1931) we have been promised a young plant by the discoverer Mr. R. E. Wicker of Pinehurst, N. C., so that we may hope to have both these interesting forms growing in this arboretum.

A third form described as L. Styraciflua suberosa Schwerin (in Mitt. Deutsch Dendr. Ges. 45:390, pl. 52. 1933) with all the branches strongly corky-winged is hardly worth distinguishing, since it represents the typical form of the tree, perhaps with the corky wings somewhat more strongly and plentifully developed than usual.

Spiraea virgata Franchet, Pl. Delavay. 199 (1890).

Spiraea myrtilloides Rehder in Sargent, P1. Wilson. 1: 440 (1913) ; Man. Cult. Trees Shrubs, 337 (1927). - Synon. nov.

When I had the opportunity to examine in the Paris herbarium the 
types of Franchet's new species of Spiraea, I found that his Spiraea virgata agrees well with the species I had described in 1913 as $S$. myrtilloides. Additional material received later shows that the species is widely distributed in western Szechuan and in Yunnan and that it is very variable, particularly in its inflorescence which may be nearly sessile or borne on a very short lateral branchlet with few leaves at the base, or on an elongated leafy branchlet up to $4 \mathrm{~cm}$. long; it may be glabrous or pubescent and may be a simple raceme with occasionally two flowers on one pedicel or the inflorescence may become corymbose with the lateral axes bearing 1-5 flowers. Such specimens approach $S$. Schneideriana Rehd. which is probably only an extreme variety of S. virgata, as I have already indicated under S. Schneideriana var. amphidoxa (op. cit. 1:450).

Cotoneaster microphylla Lindl. f. melanotricha (Franch.), comb. nov.

Cotoneaster buxifolia Wall. f. melanotricha Franchet, P1. Delavay. 224 (1890).

Yunnan: Hee-chan-men, Delavay 3742 (type; photo. and fragments in herb. Arnold Arb.); near Tali, alt. 3000 m., C. Schneider 2800, Oct. 16, 1914; eastern slopes of Likiang Snow Range, J. F. Rock 3460, May to Oct. 1922. Cult. Nursery Overrieden, Switzerland, June 1, 1938, raised from seed coll. by C. Schneider in 1914.

This variety was originally placed by Franchet under $C$. buxifolia Lindl., but differs in its glaucous papillose underside of the leaves furnished with scattered blackish hairs. It is perhaps only a form of C. microphylla var. cochleata (Franch.) Rehd. \& Wils. from which it differs apparently only in its blackish hairs.

Sorbus hybrida L. var. Meinichii (Hartm.), comb. nov.

Sorbus Aucuparia* Meinichii Lindeb. mskr. ex Hartman, Handb. Skand. Fl. ed. 11, 271 (1879). - Hjelt in Act. Soc. Faun. Fl. Fenn. 41, 1: 23 (Consp. Fl. Fenn.) (1919).

Sorbus Meinichii Hedlund in Svensk. Vetensk.-Akad. Handl. 35, 1: 49, fig. 8 (Monog. Sorbus) (1901). - Schneider, Ill. Handb. Laubholzk. 1: 675, fig. 370g (1906). - Blytt, Handb. Norges F1. 420 (1906).

Pyrus aucuparia $\times$ (aucuparia $\times$ intermedia $)$ Ascherson \& Graebner, Syn. Mitteleur. Fl. 6, 2: 105 (1906).

Sorbus aucuparia $\times$ fennica Lindman, Svensk Fanerogamfl. 305 (1918).

Since Sorbus Meinichii is generally considered as having originated as a cross between $\times S$. hybrida with one of its parents, it must be classed as a variety of the binomial which stands for that group of hybrids; special binary names for different forms of the same parentage are not allowed under the International Rules. 
Sorbus intermedia (Ehrh.) Pers. var. arranensis (Hedl.), var. nov.

Pyrus fennica Syme, Sowerby's Engl. Bot. ed. 3, 3: t. 485 (1864), non P. fennica (L.) Babington (1851).

Sorbus arranensis Hedlund in Svensk. Vetensk.-Akad. Handl. 35, 1: 60, fig. 12-14 (Monog. Sorb.) 1901. - Marshall in Jour. Bot. 54: 10 (1916).

This variety is similar to S. intermedia var. minima (Ley) Bean, but the leaves are larger and more deeply divided, the lowest sinuses reaching more than halfway to the middle.

Sorbaronia Jackii (Aronia prunifolia $\times$ Sorbus americana), hybr. nov.

Frutex, ramulis initio adpresse albo-villosis; folia infra pinnata pinnis 2-4 plerisque oblongis decurrentibus acutis vel acutiusculis serratis, superius lobata, apicem versus argute serrata, supra in costa sparse glandulosa, subtus villosa, glabrescentia, ea ramulorum florentium 3-7 $\mathrm{cm}$. longa, apice acuta vel acutiuscula, interdum pauca simplicia vel tantum lobata, ea ramulorum sterilium ad $10 \mathrm{~cm}$. longa et oblongolanceolata, manifeste acuminata; petioli 1-2 mm. longi, villosi. Inflorescentia satis densa, 3-4 cm. diam., laxe vel sparse villosa; calyx glaber vel fere glaber. Fructus ovoideus, circ. $8 \mathrm{~mm}$. longus, atropurpureus.

Nova Scotia: Halifax, near entrance to Pt. Pleasant Park, J. G. Jack 677, June 16, 1918, no. 3242, June 21 and Sept. 30, 1924. Cult. in Arnold Arboretum under no. 18262 from plants introduced by J. G. Jack in 1924; specimens in herb. A.A.: Sept. 23, 1927, Sept. 25, 1929, May 16, 1930, May 22, 1933, May 11 and July 23, 1936.

This plant is apparently a hybrid between Sorbus americana Marsh. and Aronia prunifolia (Marsh.) Rehd. (A. floribunda Lindl., A. atropurpurea Britt.) which both grow on the island. Besides these species, Aronia melanocarpa (Willd.) Ell. and Sorbus aucuparia L. are found there, the latter naturalized. The villous pubescence of the underside of the leaves and of the inflorescence excludes the former and the acuminate leaves and the small inflorescence and small fruit the latter as possible parents of this hybrid.

Photinia villosa f. Maximowicziana (Lévl.), comb. nov.

Pirus sinensis Lindl. var. Maximowicziana Léveillé in Rep. Spec. Nov. 10: 377 (1912).

Photinia villosa "(Thunb.) D. C.” Rehder in Jour. Arnold Arb. 13: 304 (1932) quoad synon. supra cit.

Korea: Quelpaert, in sylvis Haitchenam, E. Taquet, 2821, Aug. 1909 (holotype of Pirus sinensis var. Maximowicziana, photo. and iso- 
type); in sepibus Spalkai [?], E. Taquet 1456, Oct. 30, 1908. Cult. Golden Gate Park, E. Walther, Sept. 10, 1928; Atlantic Nurseries, Berlin, Md., Nov. 3, 1937; Sunridge Nurseries, Greenwich, Conn., Oct. 13, 1938; Arnold Arboretum, no. 507 (plant received in 1879 from Parsons \& Son who introduced it from Japan), June 11 \& Oct. 1887, Oct. 20, 1890 and Oct. 13, 1892.

This form differs from type chiefly in the following characters: Leaves obovate, rounded and abruptly acuminulate or nearly truncate at apex, gradually narrowed at base into a petiole 1-2 $\mathrm{mm}$. long, chartaceous, serrulate or ciliate-denticulate, midrib and veins above much impressed, elevated beneath, often rugulose above and veinlets prominent beneath, at maturity sparingly villous on the under surface or only near midrib beneath, sometimes nearly glabrous; inflorescence villous, at maturity sparingly villous (in the type specimen) or glabrous. With its subcoriaceous strongly veined leaves distinctly obovate and mostly rounded or nearly truncate at the apex, this variety looks quite distinct from the typical plant. The two numbers 507 and 2902 cultivated at the Arnold Arboretum have the leaves less strongly rounded at the apex and never truncate, and approach the typical plant.

Malus purpurea (Barbier) Rehd. f. Lemoinei (Lemoine), comb. nov.

Malus floribunda Lemoinei Lemoine, Cat. no. 196: 11 (1932).

Pyrus Lemoinei R. C. Notcutt ex Gard. Chron. ser. 3, 83: 343, fig. 165 (p. 349) (1928).

This is apparently a form of Malus purpurea which is a hybrid between $M$. pumila var. Niedzwietzkyana (Dieck) Schneid. and $\times M$. atrosanguinea (Spaeth) Schneid. It was raised by Lemoine and first mentioned in his Catalogue as cited above with a brief description. It is growing in this Arboretum and with its dark bronzy leaves and deep crimson flowers, is the most attractive of the group of hybrids belonging to $M$. purpurea.

Malus prunifolia (Willd.) Borkh. f. pendula (Bean), comb. nov. Pyrus prunifolia Willd. var. pendula Bean, Trees Shrubs Brit. Isls. 2: 291 (1914).

A form with pendulous branches in cultivation in the Kew Arboretum from which this Arboretum received scions for grafting in 1926.

Pyrus pyrifolia (Burm.) Nakai f. Stapfiana (Rehd.), comb. nov.

Pyrus sinensis sensu Stapf in Bot. Mag. 134: t. 8226 (1908) pro parte, quoad plantam depict.; non Lindl.

Pyrus serotina var. Stapfiana Rehder in Proc. Am. Acad. Arts Sci. 50: 233 (1916). 
Since Nakai has shown that Ficus pyrifolia Burmann of which he saw the type specimens in the herbarium Delessert at Geneva, is an older name for $P$. serotina Rehd., the above new combination becomes necessary for this form distinguished by rather small pyriform fruit.

Pyrus Regelii, nom. nov.

Pyrus heterophylla Regel \& Schmalhausen in Act. Hort. Petrop. 5: 581 (1878), non Pott (1800), nec (Spach) Steud.

The name $P$. heterophylla Reg. \& Schmalh. which fits this species with partly entire, partly pinnatifid to pinnatisect or trifid leaves very well, has unfortunately two older homonyms which make the name untenable, although the homonyms belong to different genera.

Pyrus heterophylla Pott in Du Roi, Harbk. Baumz. ed. 2, 318 (1800) is evidently a renaming of $P$. hybrida Moench and becomes a synonym of Sorbaronia hybrida (Moench) Schneider in Silva-Tarouca, Uns. Freiland-Laubgeh. ed. 2, 388 (1922). As author of P. heterophylla usually Du Roi is cited, but the second edition was issued after the death of Du Roi by his friend J. F. Pott who made additions to the original text indicated by being enclosed in brackets (cf. op. cit. pref. p. XI): Pyrus heterophylla is such an addition.

Pyrus heterophylla (Spach) Steudel, Nomencl. ed. 2, 2: 423 (1841) is based on Malus heterophylla Spach, Hist. Veg. 2: 138 (1834) which probably is, as suggested by Spach, a hybrid between Malus pumila and $M$. coronaria, as is also the opinion of Schneider (cf. Ill. Handb. Laubholzk. 1:719) who saw Spach's type. Malus heterophylla would then be the oldest name for this hybrid which also has originated independently in America and has often been confused with Malus Soulardii Brit. Here belongs "Matthew's Crab" and some other forms usually referred to $M$. Soulardii.

Potentilla fruticosa L. f. Wardii, nom. nov.

Potentilla fruticosa var. grandiflora Marquand in Jour. Linn. Soc. Bot. 48: 175 (1929); non Willd. (1816).

Since the epithet given by Marquand is preoccupied by $P$. fruticosa 3. grandiflora Willd. in Mag. Naturf. Fr. Berlin, 7:285 (1816), it must be changed and I propose to name it for the collector, Mr. F. Kingdon Ward.

Potentilla fruticosa var. Friedrichsenii (Spaeth) Rehd. f. Beanii, nom. nov.

Potentilla Friedrichsenii leucantha Spaeth in Mitt. Deutsch. Dendr. Ges. 19: 286 (1910) ; Rep. Spec. Nov. 13: 365 (1914). 
Potentilla fruticosa var. leucantha Bean, Trees Shrubs Brit. Isls. 2: 223 (1914). - Rehder, Man. Cult. Trees Shrubs, 423 (1927). - Non Makino (1910).

This white-flowered form is a seedling of var. Friedrichsenii which is a hybrid between typical $P$. fruticosa and var. dahurica (Nestl.) Ser. If $P$. davurica Nestl. is considered a distinct species, the binary name $X P$. Friedrichsenii Spaeth is the valid name for this hybrid and "leucantha" can stand as the name of a subdivision of this hybrid, but if transferred as a subdivision to $P$. fruticosa, it is invalidated by P. fruticosa var. leucantha Makino (in Bot. Mag. Tokyo, 24: 32. 1910) which belongs to var. mandshurica Maxim.

Rosa pendulina L. var. oxyodon (Boiss.), comb. nov.

Rosa oxyodon Boissier, Fl. Or. 2: 674 (1872). - Crépin in Bull. Herb. Boiss. 2: 261 (1895).

Rosa alpina var. oxyodon (Boiss.) Boulenger in Bull. Jard. Bot. Bruxelles, 13: 244 (1935).

Following R. Keller (in Ascherson \& Graebner, Syn. Mitteleur. Fl. 6, 1:299. 1902) and others, I take $R$. pendulina to be the oldest name applicable to this species.

Rosa carolina L. var. villosa (Best) Rehd. f. alba (Rehder), comb. nov.

Rosa lucida var. alba Anon. in Am. Florist, 12: 1098, fig. (1897).Rehder in Bailey, Cycl. Am. Hort. 4: 1554 (1902).

Rosa virginiana alba Willmott, Gen. Rosa, 1: t. opp. p. 198 (1911).

Rosa Lyoni Pursh f. alba Rehder in Jour. Arnold Arb. 3: 17 (1921) which see for further citations.

Since $R$. Lyoni Pursh is hardly separable from $R$. carolina as a distinct species, this white-flowered form which is undoubtedly a form of $R$. Lyoni must be classed under $R$. carolina .

Rosa chinensis Jacq. f. mutabilis (Corr.), f. nov.

Rosa mutabilis Correvon in Rev. Hort. 1934: 60, pl.

This rose differs from $R$. chinensis chiefly in the color of the flowers which change from sulphur-yellow to orange and red and finally to crimson. The flowers are simple, 4.5-6 cm. across, with obovate petals; the leaflets are mostly oblong-ovate gradually acuminate and on the specimens before me up to $5 \mathrm{~cm}$. long, those of the flowering branchlets smaller and comparatively broader. In the orange and yellow shades of the flowers, it resembles certain forms of $R$. odorata Sweet, but in all other characters it agrees with $R$. chinensis. 
Prunus Amygdalus Batsch f. variegata (Schneid.), comb. nov.

Amygdalus communis foliis variegatis F. J. Schultz, Abh. Bäume Oestr. 1: t. 24 (1792) ex Ind. Lond. 1: 174. - Baum. Cat. ex Loudon, Arb. Frut. Brit. 2: 675 (1838).

Prunus communis f. variegata hort. ex Zabel in Beissner, Schelle \& Zabel, Handb. Laubholz-Ben. 235 (1903), nom. - Schneider, Ill. Handb. Laubholzk. 1: 593 (1906).

A form with variegated leaves, apparently already known before 1800 .

Prunus Amygdalus f. purpurea (Schneid.), comb. nov.

Prunus communis f. purpurea hort. ex Zabel, 1. c. (1903), nom. Schneider 1. c. (1906).

A form with rose-purple flowers.

Prunus Amygdalus f. roseo-plena (Schneid.), comb. nov.

Amygdalus communis flore pleno F. J. Schultz, Abh. Bäume Oestr. 1: t. 25 (1792) ex Ind. Lond. 1: 174. - Baum. Cat. ex Loudon, 1. c. (1838). - Carrière in Rev. Hort. 1875: 370, t.

Prunus communis f. rosea plena Zabel, 1. c. (1903), nom.

Prunus communis f. roseo-plena Schneider, 1. c. (1906).

A form with double pink flowers, like the preceding known already before 1800 .

Prunus Amygdalus f. albo-plena (Schneid.), comb. nov.

Prunus communis f. alba plena Zabel, 1. c. (1903), nom.

Prunus communis f. albo-plena Schneider 1. c. (1906).

A form with double white flowers.

Prunus tomentosa f. leucocarpa, f. nov.

A typo recedit fructibus albidis.

This form differing in its yellowish white fruits is growing in the Arnold Arboretum, plants having been presented to the Arboretum by Mr. H. P. Kelsey of East Boxford, Mass., in 1930. Specimens in herbarium Arnold Arboretum; coll. July 25, 1931 (fruit) and April 28, 1936 (flowers).

$\times$ Prunus Skinneri (P. japonica $\& \times$ tenella), hybr. nov.

Frutex ramulis brunneis, cortice tertio anno longitudinaliter fisso. Folia oblongo-ovata vel oblongo-lanceolata, 3.5-5.5 cm. longa, acuminata, basi late cuneata, interdum fere rotundata, argute subsimpliciter serrulata, dentibus mucronulatis partim denticulo unico instructis, supra sparse minuteque adpresse pilosula praesertim marginem versus, subtus ad costam pilosula, ceterum glabra; petioli puberuli $2-4 \mathrm{~mm}$. longi. Flores coetanei, $2-3$; pedicelli $1-2 \mathrm{~mm}$. longi, puberuli ut calyx; 
calycis tubus anguste campanulatus circiter $3 \mathrm{~mm}$. longus; sepala tubum subaequantia vel paullo longiora, oblonga, reflexa, glanduloso-denticulata, intus extusque puberula; petala obovato-oblonga vel oblonga, supra medium dentata; stamina petalis dimidiis breviora; stylus petalis paullo brevior, in triente inferiore longe pilosus; ovarium minute dense pubescens. Fructus ovoideus, circ. $1 \mathrm{~cm}$. longus, dense subadpresse villosus.

Cult. Manitoba Hardy Plant Nursery, coll. F. L. Skinner, spring 1938 (flower; type), Aug. 25, 1938 (fruit) (in herb. Arnold Arboretum).

This hybrid was raised by Mr. F. L. Skinner from seed of $P$. japonica Thunb. It is easily distinguished from that species by the narrower nearly simply serrate leaves, broadly cuneate at base with longer petioles, the very short pedicels, the narrow-campanulate calyx, narrower sepals and petals, the pilose style and the pubescent ovary and fruit. From $P$. tenella Batsch ( $P$. nana Stokes, not Du Roi) it differs chiefly in the ovate-oblong, acuminate, closely and slightly doubly serrulate leaves, pubescent on the midrib beneath, in the short-stalked flowers and in the campanulate calyx.

\section{$\times$ Prunus Schmittii ( $P$. canescens $\& \times$ avium $)$, hybr. nov.}

Arbor parva, ramis erecto-patentibus cortice trunci rubro-brunneo, lenticellis magnis transversis, cortice ramorum in lamellas tenues solubili, ramulis hornotinis satis dense villosulis, annotinis rubro-fuscis glabris nitidulis. Folia elliptico-oblonga, 5-8 cm. longa, acuminata, basi late cuneata, dupliciter vel subsimpliciter serrata dentibus obtusiusculis, supra initio laxe adpresse pilosa, demum glabrescentia, subtus dense pilosa praecipue ad nervos, demum in facie sparse ad costam et venas laterales densius pilosa; petioli $1-2.5 \mathrm{~cm}$. longi, graciles, initio pilosi, demum fere glabri. Flores 1-3, basi involucro sub anthesi persistente circumdata; pedicelli $1-1.5 \mathrm{~cm}$. longi, sparse pilosi; calycis tubus campanulatus, 5-6 mm. longus, laxe pilosus; sepala ovata vel ovalia, circiter $2 \mathrm{~mm}$. longa, fere integra, extus laxe pilosa, intus glabra, patentia vel reflexa; petala late ovalia vel obovato-orbicularia, alborosea, 9-10 mm. longa; stamina dimidia petala aequantia; stylus glaber, stamina paullo superans. Drupa subglobosa, circ. $1 \mathrm{~cm}$. diam., putamine laevi ovoideo.

Cult. in Arnold Arb.: no. 1548-23, coll. A. Rehder, June 3, 1935 (fruit) and May 10, 1937 (flowers; type).

This hybrid was raised in 1923 from seed of $P$. canescens Bois, from which it is at once distinguished by its tree-like habit, the much larger, less pubescent leaves on longer petioles, by the larger flower with campanulate calyx, broadly oval petals about $1 \mathrm{~cm}$. long and by longer 
pedicels surrounded at the base by a large conspicuous involucre. In its general aspect it approaches $P$. avium $\mathrm{L}$., particularly in the serration and shape of the leaves, the campanulate calyx and the rather large flowers surrounded by a conspicuous involucre, but it is easily distinguished by the sparsely flaky bark of the branches, the pubescent branchlets, the persistent pubescence of the underside of the leaves and by the pilose pedicels and calyx. There are several trees of this hybrid growing in the Arboretum, now about $5 \mathrm{~m}$. tall.

I take pleasure in naming this handsome hybrid after the superintendent of the Arnold Arboretum, Mr. Louis V. Schmitt, who has been connected with the Arnold Arboretum for 33 years.

\footnotetext{
Arnold Arboretum, HARVARD University.
} 


\section{$2 \mathrm{BHL}$ Biodiversity Heritage Library}

Rehder, Alfred. 1939. "New Species, Varieties and Combinations from the Collections of the Arnold Arboretum." Journal of the Arnold Arboretum 20(1), 85-101. https://doi.org/10.5962/p.185398.

View This Item Online: $\underline{\text { https://www.biodiversitylibrary.org/item/33596 }}$

DOI: https://doi.org/10.5962/p.185398

Permalink: https://www.biodiversitylibrary.org/partpdf/185398

\section{Holding Institution}

Missouri Botanical Garden, Peter H. Raven Library

\section{Sponsored by}

Missouri Botanical Garden

\section{Copyright \& Reuse}

Copyright Status: In copyright. Digitized with the permission of the rights holder.

Rights Holder: Arnold Arboretum of Harvard University

License: http://creativecommons.org/licenses/by-nc-sa/3.0/

Rights: https://biodiversitylibrary.org/permissions

This document was created from content at the Biodiversity Heritage Library, the world's largest open access digital library for biodiversity literature and archives. Visit BHL at https://www.biodiversitylibrary.org. 